\title{
Non-governmental organizations social-economic security partnership policy
}

\author{
Aleksander Sapiński * A; Sabina Sanetra-Półgrabi ${ }^{B}$; Anna Nastuła ${ }^{\text {C }}$ \\ A Bielsko-Biala School of Finance and Law, Poland \\ ${ }^{B}$ Pedagogical University of Cracow, Poland \\ c Military University of Technology, Poland
}

Received: December 07, 2020 | Revised: December 12, 2020 | Accepted: December 31, 2020

DOI: $10.33445 /$ sds.2020.10.6.16

\begin{abstract}
The purpose of this article is to present the importance of non-governmental organization (NGO) partnerships within civil society. The idea of partnership has become a megatrend in the modern world, which seems to permeate various areas of social, economic, military and even family life. There are three main values that form the foundation of NGO partnerships in the field of security: trust, cooperation and reciprocity. Building pro-social concepts in the area of security, which will be embedded in a model based on the above-mentioned values. They are a supported search of the literature and practice of the plane for due development of new concepts, but also a place for open minds. It can therefore be concluded that the NGO acts as a bridge in the structure of the socioeconomic security system. Creating and enabling organizations to connect and enable them to achieve specific tasks and goals also creates new conditions for improving partnership networks. The organization of research work for the following text was based on the analysis of legal acts related to the objectives of sustainable development, the literature on the subject and documents resulting from the practice of economic life.
\end{abstract}

Key words: socio-economic security, NGO, partnership, sustainable development.

\section{Introduction}

Nowadays, developing a strategy of action assumes taking into account an increasing number of partners and contractors. Collaborative networks are becoming more and more effective and innovative forms of solutions both in the area of security and issues of mainly economic and business sense. Acting in favor of a chosen interest is a fundamental task of any non-governmental organization that chooses a certain section of social life on which it works and improves it in order to improve the life of the general public.

In modern society, the best social relations, both private and official, public, can be described through the theory of social exchange (Homans, G. C., 1961). In the mission of an NGO, however, the theory of social exchange should be seen more in the context of the changes that take place in subsequent generations under the influence of education and global quasiindoctrination with the noble purpose of supporting others. This situation is best illustrated by the essence of social education in European countries (Szołtysek, A.E., 2013). The essence of modern upbringing shapes the practical dimension of social exchange theory through:

- assimilating complex actions oscillating around new concepts;

- willingness to imitate new-fashioned activities with positive goals as part of a kind of trend among young people;

- copying a new value system that replaces the incompatible elements of the current value system in order to create new rules in line with the planned objectives;

\footnotetext{
* Corresponding author: Lecturer, e-mail: olek.sapinski@interia.pl, ORCID: 0000-0002-3326-2387
} 
- Moral justification of changes in the value system through the motives of social and civilization progress;

- disciplining minorities with the participation of an acceptable majority for the purpose of achieving the desired goal of change.

The impact of the changes is therefore practically visible, as the maximization of commercial profit is beginning to give way to the maximization of social profit. Of course, in the era of realization of coherent strategy of sustainable development (Zharova, L., 2020) maximization of social profit should generate twice as much commercial profit. The full effectiveness of the described assumptions is therefore possible through:

- constant monitoring of social behavior,

- integrating business, the public sphere and NGOs according to the principle of corporate social responsibility,

- building the third sector (NGO) through business and the public sphere to solve problems that other sectors will not be able to solve,

- social policy creation of NGOs in the Country and Euroregion through active creation of mechanisms of local self-government, which can work in partnership with many organizations and implement programs that they wouldn't be able to handle on their own

- recognising the value of diversity as a

\section{Material and methods}

In the presented article, the authors focused on presenting the main relationships that resulted from the research undertaken and the scientific and social work of the authors. The described concepts, especially the proposed process model, were created using the direct observation method, the individual case method and the method of analysis and criticism of literature (Apanowicz J., 2002). In this paper the authors wanted to provide direct and indirect answers to the following research questions:

1. based on what principles and concepts to build NGO partnerships on socio-economic security? positive element in the implementation of social programs (Wziątek-Stasko, A., 2012).

Archbishop F.J. Sheen (1952) presented an interesting model that can be used to actively create social policy with the participation of NGOs. It involves restoring reason to the world in 3 steps (Sheen, F.J., 2017):

1. not to rely on feelings and inventions but only on thinking and common sense;

2. not rely on prejudice in dispute resolution, but on dialogues and mediation in which each party has a voice;

3. you should not only take your own position and thoughts in your argumentation, but also take your opponent's opinion into account.

How, then, can one perceive, according to the rule of St. Benedict, one must educate and form through action and word, rather than superficial and cursory actions for show that destroy the methodology of work (Bianchi, P.G., 2009).

By collecting all the above theories and related concepts, many conclusions can be drawn concerning strategy planning, controlling these plans or work organization. However, the basic value that influences partnership policy in the third sector (NGO) is respect and mutual understanding. Based on these two foundations, it is possible to outline the concept of the work of these partnerships and the way the model works, which gives them a practical executive character.

2. Is it possible to develop a model process of partnership between NGOs and business and the public sphere in the area of socio-economic security?

3. How to integrate NGO activities with business in order to ensure socio-economic security?

From the analysis of NGO documentation from Żywiec County in Poland in 2016-2019 and its cooperation with business and local authorities, it is possible to propose a model of NGO partnership process in the field of socioeconomic security: 


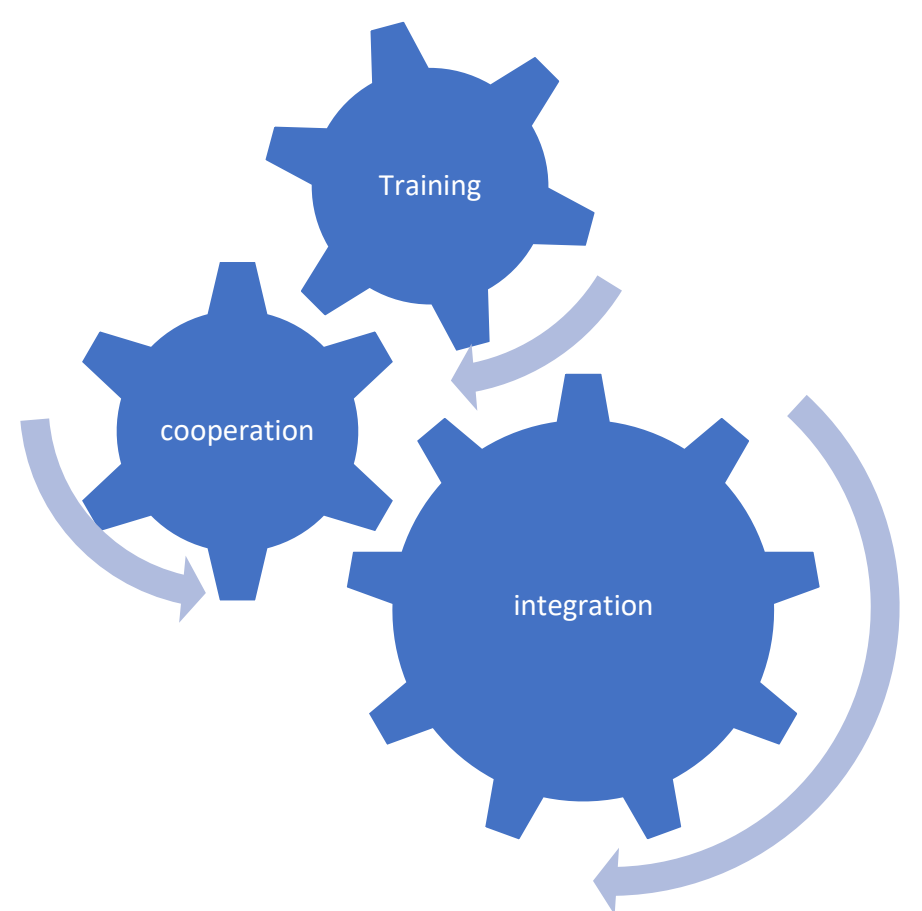

Fig. 1 The model of partnership processes between NGOs and the business and public environment in the area of economic security

\section{Results and discussion}

Building a partnership which, in accordance with the concept of sustainable development, will be a platform for building and creating innovative ventures for a specific purpose, becomes not something above average, but one of the basic phenomena in economic, defence or education. As a model we can give here the fact that people themselves strive for partnerships in their private and professional lives (Ciupka, S., 2020). That is why translating some proven patterns of Western culture can help to build a better image of the world of social and economic security. Introducing new socioeconomic security actors into the reality of local, or even regional or national security is a task that requires:

- to discern the situation of socially excluded people, and especially the reasons for their current situation,

- situational analysis indicating at least the strong and notorious sons together with the development prospects of individuals hatched from the population living in the area,

- evaluation of social opportunities and business relations for the development of labour market and occupational safety (Report of ILO, 2004).

Organizing the process of security planning in socioeconomic terms, which touches upon issues related to the processes taking place on the labour market, is in a sense a long-term process. Planning a fast-track training of people who will effectively adapt to the needs of the labour market in order to be able to earn money in order to support economic development on a micro and macro scale seems to be a desperate issue. The practical approach to the implementation of the assumptions aimed at ensuring success in the field of social and economic security, the possibility of development on a micro or even macro scale, becomes an indispensable practice of the Polish self-government and its partnership with nongovernmental organizations (NGOs). An important element of the work on training as the first stage of the process presented above is to emphasize important elements of intercultural education (Śliwerski B., 2015), which can bring measurable effects in case of the young generation. In addition to the known goals of the policy of intercultural education 
from the point of view of security, which are known to educators, it should be emphasized:

1. respect for people with different views, people with problems who need help and understanding. This point should also consider approaches to similar situations in other countries or cultural regions,

2. to deepen the competence to see opportunities in differences which, despite division, can become a bridge to success,

3. planning and organization of meetings aimed at connecting two cultures, but not only those ethnically different, but also two cultures of life, which could be described as a lifestyle that has often been imposed by circumstances beyond the control of even the socially excluded.

Discovering new opportunities for education and personal development has a humanistic dimension, which, paradoxically, when compared with the needs for socio-economic security, becomes, in a way, the foundation of work at the grassroots level. The basis of this stage of the modeled partnership process is to fight against stereotypes (Aronson E., 1999), which repeatedly effectively disrupt many social phenomena that can generate positive effects on social development in the form of changes in mental attitudes or creation of new social initiatives. The stage of education and training for socioeconomic security requires a synergy of two sources at least, i.e. the combination of at least two people for a common higher purpose, which by developing two people gives the opportunity to develop also for others. The essence and meaning of education are self-development, which is the beginning of a path of personal development, as well as the setting of a pathway for other people who are in need during a given period, maybe even without knowing it.

The stage of cooperation assumes the selection of potential institutions, persons or other entities to cooperate within the assumed goals. While making decisions about cooperation in all sectors a moral motivation is built up among participants to take action (Yarova, I., 2018). Cooperation in the concept described by the authors is to be a step before integration, i.e. before full cooperation for a common goal. As far as cooperation is concerned, one can take advantage of the division of social groups, which create social capital based on trust, i.e. the principle of cooperation. Building social capital is facilitated by creating social networks and increasing the intensity of social contacts (Błaszczuk, D.J., 2017). Trust in cooperation increases with the time of cooperation and will depend on issues related to the earlier stage of education. At this stage, in addition to respect for the other person, one should also focus on:

- partnership in cooperation and recognition of the partner's interest on an equal footing with the interest of its organization in case of realization of a common goal, especially based on the principle of acting for the public good, where there is no distribution of financial resources,

- motivating and encouraging other actors from different sectors who want to act across divisions for a common social goal by being socially responsible and demonstrating in their work how fair competition is respected,

- creating an atmosphere of friendship for both cooperating and interested people. What is important here is the equality of all partners in making decisions and setting direction.

- avoidance of anonymization (Merton, R.K., 2002) of persons taking part in joint ventures and prevention of premature withdrawal of partners during the cooperation.

- counteracting the skepticism of the partners through social dialogue and consulting experts who can present new and interesting directions of cooperation, which will allow to resist the solution of the problem for which the cooperation has been established show the direction for the development of the problematic issue in the positive sense of this statement.

The last stage, which is the integration of the activities of all sectors in a concrete goal, is the stage that can bring the most social good. Integration as a phenomenon in social sciences according to PWN Dictionary of Polish Language can be understood in many ways (Słowniki PWN):

- the process of forming a whole from a part, 
- the economic process of merging companies, departments or economies of individual countries,

- the process of integration taking place at different levels of society,

- the process of adapting the behaviour of people in a group to each other.

From the socioeconomic security point of view, it can be concluded that integration also becomes the ability of full and far-reaching cooperation, which brings tangible trilateral effects (i.e. integrated entities and the socioeconomic environment). The inclusion of integration as one of the skills raises many problems related to, for example, changes in entities, communication and the sense of security in entities in connection with the changes that take place in integrated cooperation for socio-economic security. Also important is the idea itself, which in many cases has to build a bridge between social exclusion and financial security, between which there is usually a gap (Uzoma, A., 2020). Thus, integration alone does not mean the integration of two entities as in the case of company mergers, but the integration of activities with a specific and intended purpose.

\section{Case study NGO "BEST PROEKO" and it work.}

"BEST PROEKO" has launched a process that is innovative, difficult and necessary. The fact that it is a necessary process is evidenced by the fact that we still exist. "BEST PROEKO" gives the competent people this public, social and economic task which is very desirable for further implementation. Evil happens by itself, it is enough to do nothing. But good is born in pain and difficulty, sometimes seemingly insurmountable, but good always wins where necessary things are done. And so, in this case, the difficulties are overcome. Integration requires that this work be continued by competent institutions and that they do it well, so that the person is most important, that the official is a guide for the person in need. There is public awareness of the activity of social integration as a social and economic security task and the need for such activity. It is work on one's own bread, taking a fishing rod, not acceptance or extortion of a ready-made fish, the work of people who bring the common good, work and taxes to the state budget or the municipality, should be the right and duty of every citizen. Social assistance should promote human development and not the development of social pathology, which unfortunately in many cases becomes hereditary and threatens the family. In its integration work, "BEST PROEKO" currently wants to focus on the fundamental statutory activities of the Association: a sustainable, integrated and sustainable development of rural areas, where man is the most important, and therefore the conditions and environment, rights and obligations require specific and integrated common actions for the common good. In this direction, the NGO is involved and cooperates with organizations concerned with the protection of the Polish countryside and family, the reconstruction of traditional and family agriculture, and at the same time modern, pastoralism, as well as the reconstruction of proper farmer-consumer, village-city, food sovereignty and national food security.

This is also a range of tasks that include counteracting rural poverty and the spreading social pathology, the main reason for which is an inconsistent with the constitutional principle of integrated and sustainable development, a nontransparent law that must be changed in order to prevent the social and economic destruction of the country.

\section{Conclusions}

The analysis and deliberations that have been carried out include the conclusion that an effective NGO partnership policy in the socioeconomic field requires:

1. changes in the law giving greater flexibility to local government officials and greater benefits for entrepreneurs wishing to work with NGOs for common socio-economic security,

2. changes in the policy of financing social policy projects, which would consist in the 
organization of continuing education of adults at risk of social exclusion in the field of hard professional skills in agreement with employers,

3. establishing an effective system for monitoring entities covered by state aid. To this end, it is proposed to reward in subsequent grants entities supporting the third sector (NGOs) and other organizations supporting the labour market, the excluded and young people entering into adult life,

4. promotion of social and student cooperatives and change of regulations concerning execution of commune tasks by such entities operating on the territory of a given commune or district,

5. introduction to the education system in schools of common subjects such as volunteerism and upbringing to entrepreneurship, which would teach cooperation and setting goals, and most of all, the pursuit of a specific goal in the area covered by social needs, which can be implemented by NGOs,

Focusing on new, innovative companies to solve social and economic problems by subsidizing those entities that are most effective and placing their representatives in the bodies that grant funding for NGOs and social policy support.

\section{References}

Apanowicz J. (2002) Metodologia ogólna. Gdynia: Wydawnictwo "Bernardinium", p. 72.

Aronson E. (1999) Człowiek istota społeczna. Warszawa: PWN, p. 357.

Bianchi, P.G. (2009) Duchowość i zrządzanie czyli reguła św. Benedytka w strategii przedsiębiorstw. Kraków: TYNIEC Wydawnictwo Benedyktynów, pp. 109-110.

Błaszczuk, D.J., Fazlagić, J., Skikiewicz, R. (2017) Zaufanie i kapitał społęczny w polskim biznesie. Warszawa: Wydawnictwo AFiB Vistula, p. 36.

Ciupka, S. (2020) The stability of the world image in creating a global sense of security. Scientific Journal of Bielsko-Biala School of Finance and Law, 24(2), pp. 5-9. DOI: 10.5604/01.3001. 0014.3278.

Homans, G. C. (1961) Social behavior: Its elementary forms. New York: Harcourt, Brace, \& World.

Merton, R. K., (2002) Teoria socjologiczna i struktura społęczena. Warszawa: PWN, p.203.

Report of ILO (2004) - Economic security for a better world. Geneva: International Labour Office, ISBN 92-2-115611-7

Sheen, F. J. (2017) Warto żyć! Kraków: Wydawnictwo Elpil, p. 306.

Śliwerski B. (2015) Współczesne teorie i nurty wychowania. Kraków: Impuls, p.312.
Słowniki PWN. Available from: https://sjp.pwn.pl/ slowniki/integracja.html

Szołtysek, A.E. (2013) Filozofia edukacji. Kształtowanie umysłu. Kraków: Impuls, pp.157162.

Uzoma, A., Adetiloye, K. A.; Esther A.,Eke P. and Godswill O. O. (2020). Social integration and financial inclusion of forcibly displaced persons in Sub-Saharan African countries. Problems and Perspectives in Management, 18(3), 170-181. DOI: $10.21511 / p p m .18(3) .2020 .15$

Wziątek-Stasko, A. (2012) Diversity management. Narzędzie skutecznego motywowania pracowników. Warszawa: Difin.

Yarova, I., Mishenia H., (2018) Socio-ecological and economic content of development of human resources and laobur motivation in the system of spatial forestry organization [in:] Human Capital Management. Innovative aspects of transformational economies. Ruda Śląska: Omnidium, pp. 18-19.

Zharova, L. (2020) Sustainable development of territories in the framework of smart initiatives. Scientific Journal of Bielsko-Biala School of Finance and Law, 23(4), pp. 61-65. DOI: 10.5604/01.3001.0013.6826. 